\title{
Meningkatkan Semangat Mengonsumsi Jus Melalui Boba
}

\author{
Annisa Nurintha Fitri*1, Fahmi Mahmuddin Siregar ${ }^{2}$, Lestari Bunga Pertiwi ${ }^{3}$, Dini Safitri ${ }^{4}$ \\ 1,2,3,4Program Studi Ilmu Komunikasi, Fakultas Ilmu Sosial, Universitas Negeri Jakarta \\ *e-mail: annisa.nurintha@gmail.com¹, fahmimahmuddin24@gmail.com², lelestaribunga@gmail.com³, \\ dinisafitri@unj.ac.id ${ }^{4}$
}

\begin{abstract}
Boba is a bubble tea made from tapioca flour and has a sweet taste. However, not a few boba that uses sugar in excess which is very dangerous for human health. At the present time all things can be viral quickly, something new will quickly spread in the community. A thing that is trending in the community will affect one's desires. As is currently developing boba, but many boba is not good for health. Therefore, we want to create healthy boba made from natural ingredients that can maintain health. Boba is different from boba in general. Fruit juice mixture that will add properties for health and fitness. We use Instagram social media to make observations and dedication even though in the midst of the 19th outbreak of Covid this service will continue.
\end{abstract}

Keywords: Juice, Boba, Health, Efficacy

\begin{abstract}
Abstrak
Boba adalah bubble tea yang terbuat dari tepung tapioka dan memiliki rasa yang manis. Namun, tidak sedikit boba yang menggunakan gula secara berlebihan yang sangat berbahaya untuk kesehatan manusia. Pada saat zaman sekarang semua hal dapat viral dengan cepat, sesuatu yang baru akan cepat menyebar di masyarakat. Sebuah hal yang sedang tren dimasyarakat akan mempegaruhi keinginan seseorang. Seperti halnya saat ini sedang berkembang boba, namun banyak boba tidak baik untuk kesehatan. Oleh karena itu, kami ingin menciptakan boba sehat yang terbuat dari bahan alami yang dapat menjaga kesehatan. Boba yang berbeda dengan boba pada umumnya. Campuran jus buah yang akan menambah khasiat untuk kesehatan dan kebugaran tubuh. Kami menggunakan media sosial Instagram untuk melakukan observasi dan pengabdian walaupun ditengah wabah Covid 19 pengabdian ini akan tetap berjalan.
\end{abstract}

Kata kunci : Jus, Boba , Kesehatan, Khasiat

\section{PENDAHULUAN}

Kesehatan merupakan sesuatu yang bisa didapatkan lewat berbagai cara. Selain berolahraga, Asupan yang masuk ke dalam tubuh juga perlu diperhatikan. Salah satu asupan sehat dan juga nikmat adalah jus. Terkait hal tersebut, terdapat hal yang menjadi perhatian bagi penulis yaitu minimnya semangat mengonsumsi jus di masyarakat. Saat ini, masyarakat lebih memilih minuman-minuman cepat saji yang minim khasiat bahkan berdampak negatif bagi tubuhnya.

Berbagai makanan dan minuman instan diketahui memiliki zat tambahan di dalamnya yaitu zat aditif yang digunakan untuk tujuan tertentu. Zat aditif memiliki dampak yang berbahaya bagi tubuh karena dapat menimbulkan gangguan perilaku seperti gangguan tidur, gangguan konsentrasi, gangguan emosi, serta juga dapat mempengaruhi fungsi otak (Rosita \& Sophia, 2019). Sebuah slogan mengatakan "Kesehatan adalah segalanya, tanpa kesehatan segalagalanya tidak berarti", yang berarti bahwa harus ada upaya dalam diri kita sendiri untuk menjaga Kesehatan. Tidaklah berarti segala keinginan terpenuhi, apabila kita tidak sehat (Widiyani \& Triatma, 2013).

Pada saat zaman sekarang semua hal dapat viral dengan cepat, sesuatu yang baru akan cepat menyebar di masyarakat. Sebuah hal yang sedang tren di masyarakat akan mempegaruhi keinginan seseorang. Seperti halnya saat ini sedang berkembang boba, entah itu dalam minuman maupun makanan bahkan mie instanpun ada variasi boba. Begitu ngetrennya di masyarakat 
membuat boba menjadi trendsetter. Dalam program kreativitas ini kami menggunakan boba untuk kreativitas kami. Boba yang memiliki eksistensi yang tinggi membuat kami tertarik untuk menjadikan boba sebagai bahan program kreativitas kami.

Pada saat ini boba bukanlah suatu minuman yang asing lagi ditelinga generasi milenial maupun berbagai generasi lain. Biji-bijian hitam dibuat dari tepung ubi,gula,perisa tambahan dan tentunya air yang menjadi satu kesatuan berbentuk Black Pearls, minuman ini berasal dari negara Taiwan (Ismail, 2020). Boba adalah bubble tea yang terbuat dari tepung tapioka dan memiliki rasa yang manis. Namun, tidak sedikit boba yang menggunakan gula secara berlebihan yang sangat berbahaya untuk kesehatan manusia. Oleh karena itu, kami ingin menciptakan boba sehat yang terbuat dari bahan alami yang dapat menjaga kesehatan. Boba yang berbeda dengan boba pada umumnya. Campuran jus buah yang akan menambah khasiat untuk kesehatan dan kebugaran tubuh. Manfaat buah dapat juga menghilangkan segala penyakit dalam tubuh. Banyak penelitian yang menyebutkan berbagai macam manfaat buah bagi kesehatan, contohnya seperti buah mentimun yang dapat menjadi obat untuk hipertensi, buah mentimun dapat menurunkan tekanan darah secara signifikan jika dikonsumsi secara rutin (Tjiptaningrum \& Erhadestria, 2015). Buah yang dikonsumsi juga berbeda dengan obat kimia lainnya, buah tidak menimbulkan efek candu jika dikonsumsi. Dalam mengonsumsi jus buah tentu akan mendapatkan gizi dan juga menjaga kesehatan. Meningkatkan energi dan menambah kebutuhan vitamin dalam tubuh. (Suryana, 2018) oleh sebab itu dalam kegiatan ini kami menciptakan inovasi jus buah sebagai pendamping boba. Dijelaskan dalam (Arianto, 2018) bahwa dalam merawat kesehatan tubuh kecukupan air akan sangat membantu organ-organ tubuh untuk menjalankan fungsinya secara optimal sehingga akan memberikan efek bagi terjaga dan terpeliharanya kesehatan tubuh.

Dalam program kreativitas ini kami memberikan pengabdian kepada masyarakat untuk membuat boba sehat yang sangat memliki banyak khasiat. Kami membuat tutorial boba sehat yang berkhasiat dan kami share menggunakan media IGTV pada fitur instagram. Kemudahan dalam menggunakan media sosial diharapkan dapat meningkatkan pelayanan informasi dan mempermudah kegiatan penyuluhan (Prayoga, 2017). Kami menggunakan instagram sebagai pengenalan program kami sebab media sosial yang memiliki kunjungan terbanyak oleh generasi milenial dan beberapa generasi lain adalah instagram. Kehadiran media sosial dan semakin berkembangnya jumlah pengguna dari waktu ke waktu memberikan fakta menarik betapa kekuatan internet bagi kehidupan kita (Mulawarman \& Nurfitri, 2017). Menurut Kaplan \& Haenlein (2010) dalam media sosial memungkinkan terjadi pertukaran informasi secara usergenerated content, yaitu informasi-informasi di media sosial dipertukarkan dengan media audiovisual dalam berbagai platform (Erza \& Rosini, 2018).

Program kreativitas ini tentu memiliki tujuan, yaitu memberikan inovasi baru mengenai minuman yang sedang tren tanpa menyampingkan kesehatan dan dapat memberikan tutorial pembuatan boba sehat yang tentu bermanfaat untuk semua kalangan. Terlebih lagi, Indonesia memiliki sumber daya alam yang beragam untuk diolah baik dari segi pangan sumber karbohidrat, protein, vitamin, dan sebagainya (Ramses et al., 2018).

\section{METODE}

Dalam program kreativitas ini tentu memiliki tujuan yaitu, memberikan inovasi baru mengenai minuman yang sedang tren tanpa menyampingkan kesehatan dan dapat memberikan tutorial pembuatan boba sehat yang tentu bermanfaat untuk semua kalangan. Target dalam kegiatan ini adalah terutama generasi milenial yang sudah tidak asing lagi dengan boba dan seluruh kalangan yang ingin mengikuti tren namun, tidak lupa akan kesehatan. Dalam kegiatan ini mendapatkan hasl respon yang sangat baik dari followers, baik dari segi like dan comment. Followers menyampaikan bahwa tutorial ini sangat bermanfaat dan dapat menginspirasi. Followers juga mengikuti tutorial membuat boba sehat dari rumah aja sebab masa pandemi ini. 


\section{HASIL DAN PEMBAHASAN}

Pengabdian yang kami lakukan merupakan suatu usaha dari mahasiswa menyebarluaskan kepada masyarakat tentang ilmu pengetahuan, teknologi, dan suatu ide baru yang diciptakan. Hal tersebut memberikan pengetahuan baru kepada masyarakat mengenai minuman kekinian yang dapat dikonsumsi secara sehat oleh semua kalangan. Dalam bidang ekonomi, kami dapat memajukan motivasi masyarakat untuk menjual kembali hasil produk kami dan dapat dibuat sendiri oleh masyarakat karena prosesnya tidak rumit.

Kami telah melakukan serangkaian proses berpikir dan praktek untuk produk kami ini. Sesuai dengan tujuan kami, kami ingin membangun masyarakat yang sehat dan meningkatkan awareness terhadap konsumsi minuman yang kurang sehat dan menggantinya menjadi minuman yang lebih sehat. Lifestyle masyarakat Indonesia cenderung mengabaikan kesehatan diri sendiri, karena menganggap imun tubuhnya kuat. Tetapi, dibalik itu semua terdapat bahaya yang mengancam.

Produk kami diciptakan dari bahan-bahan alami yang dapat menyehatkan tubuh. Bahan utamanya adalah sayur-sayuran yang diproduksi menjadi minuman jus boba menyehatkan.

Pada perjalanan prosesnya, saat kegiatan pengabdian ini berlangsung sedang terjadi pandemi di seluruh dunia termasuk Indonesia. Oleh karena itu, kami mengalami kendala yaitu terhambatnya kegiatan pengabdian ini. Namun, kami dapat mengatasinya melalui metode dari rumah. Kami menyebarluaskan kegiatan kami melalui media sosial Instagram. Respon yang didapatkan sangat baik. Followers kami di Instagram sangat antusias dengan program ini. Kami pun telah mendemonstrasikan kepada para followers bagaimana cara membuat boba yang sehat tersebut melalui postingan IGTV. Kami mendapatkan 55 audiens yang menonton tayangan kami. Terdapat pula feedback dari followers yaitu berupa pujian dan pertanyaan seputar boba sehat kami.

Dalam kegiatan pengabdian masyarakat ini terdapat berbagai macam bahan-bahan yang dibutuhkan. Kegiatan ini memerlukan beberapa macam bahan dan ada beberapa bahan yang diganti agar minuman ini tetap sehat untuk dikonsumsi. Dapat dilihat pada Tabel 1 berikut ini bahan yang diperlukan dalam pembuatan boba sehat

Tabel 1. Bahan yang dibutuhkan untuk membuat Boba Sehat

\begin{tabular}{lll}
\hline No & \multicolumn{1}{c}{ Bahan } & \multicolumn{1}{c}{ Kebutuhan } \\
\hline 1. & Sayur wortel & 2 potong sayur \\
2 & Sayur Pokcoy & 1 ikat sayur \\
3. & Madu Murni & 2 sendok makan \\
4. & Tepung Tapioka & 5 sendok makan \\
5. & Buah Segar $($ jeruk $)$ & 1 Buah \\
\hline
\end{tabular}

Cara membuat Boba sehat, setelah menyiapkan semua bahan pertama yang dapat dilakukan adalah memotong sayuran menjadi kecil-kecil. Setelah itu, tahap kedua dipotong masukkan potongan tersebut kedalam blender dan beri sedikit air dan madu agar menjadi seperti pasta. Jika sudah tahap ketiga tuangkan tepung tapioka ke wadah sebanyak 5 sendok kemudian campur dengan pasta sayuran tersebut. Jika sudah tahap keempat kalau sudah tercampur dengan rata kemudian panaskan adonan dengan kompor sampai menggumpal. Tahap kelima bentuklah adonan menjadi bulatan kecil sesuai dengan banyak adonan. Tahap keenam rebus boba sampai benar benar matang. Jika sudah matang tahap ketujuh blender lah jus buah yang sudah disiapkan. Jika jus sudah siap masukan boba yang sudah matang kedalam jus. Kemudia minuman boba sehat sudah siap dinikmati. 


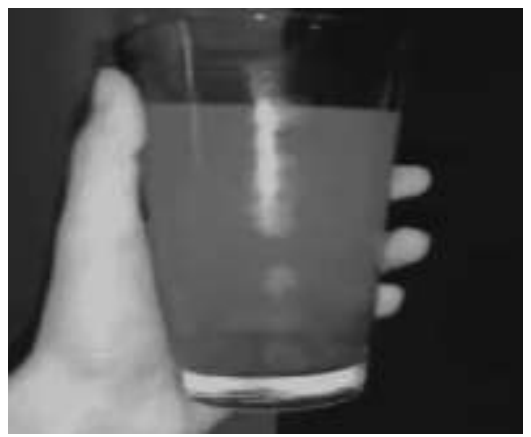

Gambar 1. Jus Boba Sehat

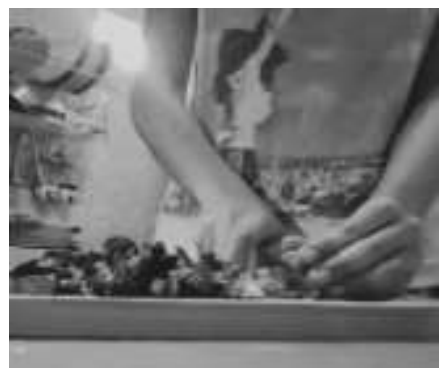

(a)

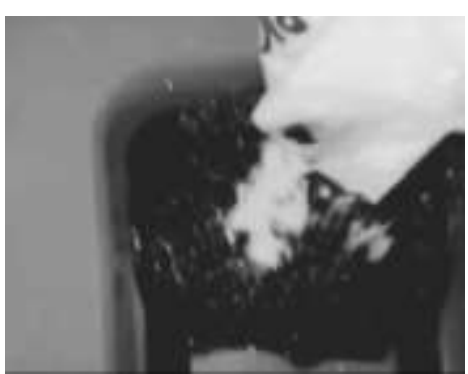

(b)

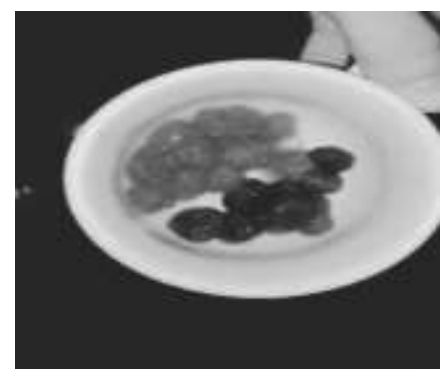

(c)

Gambar 2. Pemotongan sayur (a) pemberian tepung tapioka (b) bentuk adonan menjadi boba

Gambar diatas adalah gambar yang menjelaskan cara pembuatan boba sehat, dimana pada gambar 1 adalah prosuk boba sehat yang sudah siap dinikmati. Kemudian pada gambar (a) merupakan proses pemotongan sayur pokco dan wortel sebagai bahan dasar boba sehat. Lalu di gambar (b) adalah pencampuran antara adonan wortel dan pokcoy yang telah diolah menjadi pasta dengan tepung tapioka, agar boba menjadi kenyal. Terakhir adalah kegiatan merebus adonan boba sampai matang, adonan berwarna hijau dan orange seperti bahan dasarnya dan siap untuk disatukan dalam jus buah yang sehat. Boba sehat siap dinikmati oleh semua kalangan.

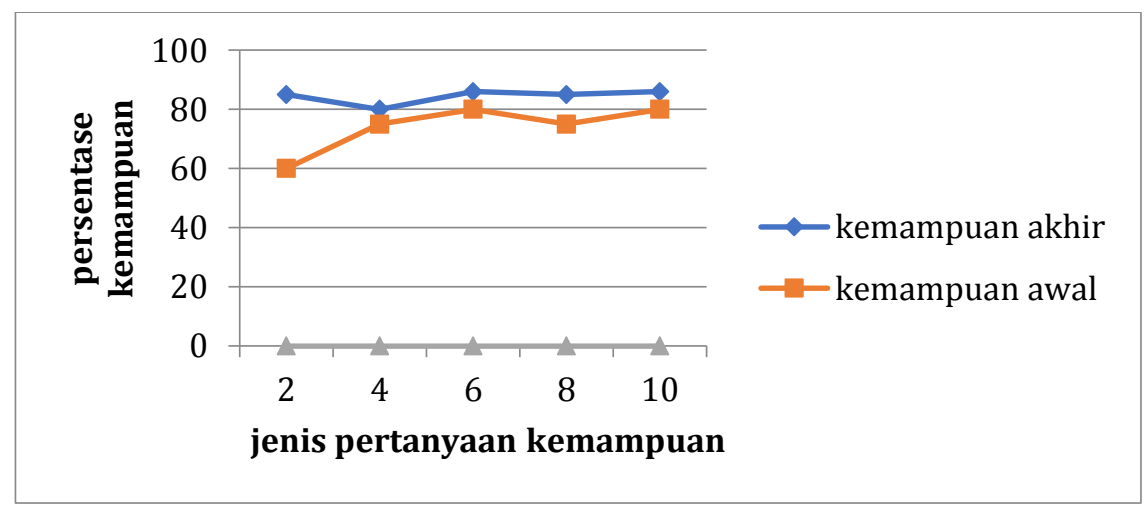

Gambar 3. Hasil test kemampuan dasar (\%) peserta pelatihan cara membuat boba sehat di rumah

Berdasarkan gambar grafik diatas dapat dikatakan bahwa, kemampuan peserta dalam mengikuti cara pembuatan boba dirumah saja . Dimana kemampuan awal para peserta belum terlalu berhasil dalam melakukan percobaan membuat boba sehat dirumah saja. Persentase percobaan awal para peserta memiliki persentase dari 60-80 persen. Namun, peserta terus mencoba agar dapat membuat boba sehat dirumah saja dengan mengikuti tutorial yang telah 
dibuat. Oleh karena itu kemampuan akhir peserta memiliki kenaikan dalam segi persentase yaitu mencapai 80-85 persen.

\section{KESIMPULAN}

Kegiatan ini dilakukan disela-sela pandemi covid 19 yang membuat kita memberikan program melalui fitur media sosial. Kegiatan ini memberikan manfaat untuk orang yang sedang dirumah aja ditengah wabah covid 19 untuk tetap produktif membuat boba, boba yang sedang viral saat ini. Namun, boba yang dibuat adalah boba sehat dari bahan dasar alami.

Kegiatan ini mengedukasi masyarakat untuk tetap mengikuti tren tanpa melupakan kesehatan tubuh ditengah wabah covid 19. Meningkatkan rasa sosialiisasi dan mendekatkan diri bersama keluarga tercinta dengan membuat boba sehat bersama dirumah saja. Dari kegiatan pengabdian masyarakat ini dapat disimpulkan bahwa dalam kegiatan ini terdapat kelebhan serta kekurangan, berikut adalah kelebihan dan kekurangannya:

Kelebihan

1. Kegiatan ini bermanfaat untuk memberikan pengabdian kepada masyarakat agar dapat mengkonsumsi minuman kekinian yang sehat.

2. Semakin banyak orang yang tetap kekinian namun tetap menjaga kesehatannya.

3. Banyak orang yang mengikuti tutorial boba sehat untuk membuatnya dirumah sendiri Kekurangan

1. Tidak semua orang menyukai sayuran dan buah-buahan

2. Tidak semua orang senang membuat home made

3. Tidak semua orang menyukai boba

Kemungkinan perkembangan selanjutnya adalah kami akan terus menyebar luaskan produk sehat kami ke masyarakat agar tetap bermanfaat untuk orang banyak terutama dalam segi kesehatannya namun tetap kekinian atau mengikuti perkembangan zaman.

\section{DAFTAR PUSTAKA}

Arianto, Y. C. K. (2018). 56 Makanan Ajaib dan Manfaatnya untuk Kesehatan dan Kecantikan. Bogor: Venom Publisher.

Erza, E. K., \& Rosini. (2018). Perilaku Informasi Remaja Terhadap Viral Challenge Di Media Sosial. Yarsi Academic Journals, 3(1), 11-21.

Ismail, S. (2020). Boba Girl. Selangor: Open Bridge Publications Sdn. Bhd.

Mulawarman, \& Nurfitri, A. D. (2017). Perilaku Pengguna Media Sosial beserta Implikasinya Ditinjau dari Perspektif Psikologi Sosial Terapan. Buletin Psikologi, 25(1), 36-41.

Prayoga, K. (2017). Pemanfaatan Media Sosial Dalam Penyuluhan Pertanian Dan Perikanan Di Indonesia. Agriekonomika Trunojoyo Journal, 6(10), 32-43.

Ramses, R., Ashari, E., \& Ramdani, R. (2018). Inovasi Minuman Dan Panganan Berbahan Baku Bidara Laut (Ximenia Americana) Dan Mangrove Dari Pesisir Kota Batam. Dinamisia: Jurnal Pengabdian Kepada Masyarakat, 2(2), 197-204.

Rosita, B., \& Sophia, A. (2019). Penyuluhan Kesehatan Bahaya Makanan Yang Mengandung Zat Kimia Pada Murid Sdn 06 Balai Talang Kecamatan Guguak Kabupaten 50 Kota Jurnal Abdimas Kesehatan Perintis. Jurnal Abdimas Kesehatan Perintis, 1(1), 31-34.

Suryana, D. (2018). Manfaat Buah: Manfaat Buah-buahan. Dayat Suryana Independent.

Tjiptaningrum, A., \& Erhadestria, S. (2015). Manfaat Jus Mentimun (Cucumis sativus L.) sebagai Terapi untukHipertensi. Jurnal Kedokteran Universitas Lampung, 5(1), 112-116.

Widiyani, S., \& Triatma, B. (2013). Penyuluhan Gizi Dan Kesehatan Serta Pembuatan Jus Sehat Untuk Lansia Agar Tetap Tampil Sehat Dan Ceria. Unnes Scientific Journals, 17(1), 53-60. 